\title{
Daya Antibakteri Ketepeng Cina (Cassia alata L.) Terhadap Staphylococcus aureus, Pseudomonas aerugenosa, dan Klebsiella pneumonia
}

\author{
Qurrotu A'yunin Lathifah ${ }^{1}$, Dora Dayu Rahma Turista ${ }^{2}$, Eka Puspitasari ${ }^{3}$ \\ ${ }^{1}$ Program Studi D III Teknologi Laboratorium Medis STIKes Hutama Abdi Husada Tulungagung, Jawa Timur \\ ${ }^{2}$ Departemen Pendidikan Biologi, Fakultas Keguruan dan Ilmu Pendidikan, Universitas Mulawarman, \\ Samarinda, Kalimantan Timur \\ ${ }^{3}$ Program Studi D III Teknologi Laboratorium Medis STIKes Hutama Abdi Husada Tulungagung, Jawa Timur
}

\begin{abstract}
Abstrak
Penyakit kulit akibat infeksi banyak dijumpai di Indonesia dan menjadi masalah besar di bidang kesehatan. Masyarakat telah menggunakan daun ketepeng cina (Cassia alata L.) sebagai obat penyakit kulit. Tujuan penelitian ini untuk mengetahui aktivitas dan efektivitas antibakteri ekstrak daun ketepeng cina terhadap bakteri Staphylococcus aureus, Pseudomonas aerogenosa, dan Klebsiella pneumonia. Metode uji yang digunakan yaitu difusi disk (Kirby Bauer). Sampel yang digunakan berupa ekstrak etanol daun ketepeng cina konsentrasi $10 \%$, $30 \%, 50 \%, 70 \%$, dan $90 \%$. Hasil penelitian ini menunjukkan adanya zona hambat di area sekitar disk yang berisi ekstrak. Diameter zona hambat bakteri gram negatif dalam penelitian ini relatif lebih besar dibanding gram positif. Hal ini dikarenakan ekstrak yang digunakan dalam penelitian agak encer. Kesimpulan yang diperoleh dalam penelitian ini ekstrak daun ketepeng cina memiliki aktivitas antibakteri terhadap bakteri Staphylococcus aureus, Pseudomonas aeruginosa dan Klebsiella pneumonia. Konsentrasi ekstrak yang paling efektif menghambat pertumbuhan bakteri Staphylococcus aureus adalah 70\%, dan konsentrasi 90\% merupakan konsentrasi yang paling efektif dalam menghambat pertumbuhan bakteri Pseudomonas aeruginosa, serta Klebsiella pneumonia..
\end{abstract}

Kata Kunci : antibakteri, ketepeng cina, staphylococcus aureus, pseudomonas aeruginosa, klebsiella pneumonia

\section{Antibacterial Power Of The Ketepeng Cina (Cassia alata L.) Against Staphylococcus aureus, Pseudomonas aerugenosa, and Klebsiella pneumonia}

\begin{abstract}
Infectious skin diseases are common in Indonesia and become a major problem in the health sector. The community has used Ketepeng Cina leaves (Cassia alata L.) as a medicine for skin diseases. The purpose of this study was to determine the antibacterial activity and effectiveness of Ketepeng Cina leaf extract against Staphylococcus aureus, Pseudomonas aeruginosa, and Klebsiella pneumoniae bacteria. The test method used is disk diffusion (Kirby Bauer). The samples used were ethanol extract of Ketepeng Cina leaves with concentrations of $10 \%, 30 \%, 50 \%, 70 \%$, and $90 \%$. The results of this study indicate an inhibition zone in the area around the disk containing the extract. The diameter of the inhibition zone for gram-negative bacteria in this study is relatively larger than that of gram-positive. This is because the extract used in the study is rather runny. The conclusions obtained in this study were the Ketepeng Cina leaf extract had antibacterial activity against Staphylococcus aureus, Pseudomonas aeruginosa and Klebsiella pneumoniae bacteria. The concentration of the extract that was most effective at inhibiting the growth of Staphylococcus aureus bacteria was $70 \%$, and the concentration of $90 \%$ was the most effective concentration in inhibiting the growth of the bacteria Pseudomonas aeruginosa, and Klebsiella pneumoniae.
\end{abstract}

Keywords: : antibacterial, Ketepeng cina, Staphylococcus aureus, Pseudomonas aeruginosa, Klebsiella pneumoniae

Korespondensi: Qurrotu A'yunin Lathifah, Program Studi Teknologi Laboratorium Medis STIKes Hutama Abdi Husada Tulungagung, Jalan Dr. Wahidin Sudiro Husodo No. 1 Tulungagung Jawa Timur, mobile 081216272206,e-mail 21ayunin@gmail.com 


\section{Pendahuluan}

Indonesia merupakan negara beriklim tropis yang menjadikan infeksi kulit banyak dijumpai. Infeksi kulit menjadi permasalahan yang cukup berarti di bidang kesehatan. Pada tahun 2010 tercatat penyakit kulit dan jaringan subkutan lainnya menempati urutan ketiga dari 10 besar penyakit pasien rawat jalan di rumah sakit se-Indonesia. Sebesar $60,77 \%$ dari 247.179 kasus penyakit kulit merupakan kasus baru (Kementerian Kesehatan Republik Indonesia 2012)

Sekitar 7-10\% infeksi kulit pada anakanak disebabkan oleh bakteri Staphylococcus aureus (Novard, Suharti, and Rasyid 2019). Bakteri ini merupakan penyebab utama nosokomial di masyarakat (Yacob and Endriani 2012). Pseudomonas aeruginosa menempati urutan ketiga bakteri penyebab infeksi oportunitis (Anggraini, Yulindra, and Savira 2018). Sifat patogen dari Pseudomonas aeruginosa dapat menyebabkan keadaan invasif pada pasien dengan penyakit kritis. Bakteri ini sering ditemukan di Rumah Sakit sebagai penyebab infeksi nosokomial (Putri, Rasyid, and Rahmatini 2014). Klebsiella pneumonia merupakan bakteri penyebab infeksi nosokomial yang sering didapatkan dari Rumah Sakit pada pasien rawat inap (Olivia 2017).

Salah satu tumbuhan yang berpotensi untuk pengobatan penyakit kulit adalah ketepeng cina. Ketepeng cina mengandung alkaloid, saponin, flavonoid, tannin, dan antrakuinon (Murni, Gunawan, and Janitra 2014). Daun ketepeng cina telah terbukti memiliki aktifitas antibakteri dan antifungi. Ekstrak daun ketepeng cina juga mampu menghambat pertumbuhan bakteri Bacillus cereus, S. aureus, E. coli, dan Salmonella typhi dengan daya hambat lemah, sedang, dan kuat (Nurlansi and Jahidin 2018).

Masyarakat desa Prigi Trenggalek memanfaatkan daun ketepeng cina untuk mengobati penyakit kulit. Pengobatan dilakukan secara tradisional, yaitu dengan cara menumbuk dan melumurkannya ke bagian kulit yang gatal. Kulit gatal yang diobati secara rutin akan berangsur sembuh. Ekstrak daun ketepeng cina mampu menghambat pertumbuhan bakteri $S$. aureus tetapi tidak mampu menghambat pertumbuhan E.coli (Yacob and Endriani 2012). Ekstrak daun ketepeng cina juga mampu menghambat pertumbuhan bakteri $R$. solanacearum dan $S$. sobrinus (Egra et al. 2019).
Berdasarkan uraian tersebut perlu dilakukan penelitian yang bertujuan untuk mengetahui aktivitas antibakteri ekstrak daun ketepeng cina terhadap bakteri Staphylococcus aureus, Pseudomonas aerogenosa, dan Klebsiella pneumonia. Diharapkan ekstrak daun ketepeng cina nantinya dapat menjadi obat alternatif dalam mengatasi berbagai penyakit yang disebabkan oleh bakteri.

\section{Metode}

Desain penelitian ini adalah eksperimental laboratorik dengan jenis post-test only control group. Penelitian ini dilaksanakan pada bulan Nopember - Desember 2020 di Laboratorium Mikrobiologi STIKes Hutama Abdi Husada Tulungagung. Pembuatan ekstrak dilakukan di Laboratorium Herbal Medica Materia Batu Malang Jawa Timur.

Bahan yang digunakan dalam penelitian ini adalah daun ketepeng cina (Cassia alata L.), etanol, isolat bakteri Staphylococcus aureus, Pseudomonas aerogenosa, dan Klebsiella pneumonia serta media MHA dan disk blak mikrobiologi. Peralatan yang digunakan yaitu peralatan gelas, rotary evaporator, rak tabung, cawan petri, ose, bunsen, inkubator, dan penggaris.

Penelitian ini diawali dengan pembuatan ekstrak ketepeng cina. Daun ketepeng cina dicuci bersih, dipotong-potong dan dikeringanginkan. Daun ketepeng cina yang sudah kering dihaluskan kemudian dimaserasi menggunakan etanol. Hasil maserasi disaring dan filtratnya dipekatkan menggunakan rotary evaporator. Ekstrak pekat yang diperoleh digunakan untuk uji aktivitas antibakteri dan uji fitokimia yang mengacu pada penelitian sebelumnya meliputi uji flavonoid, tannin, saponin, fenol, alkaloid, terpenoid, dan steroid (Ningsih, Zusfahair, and Kartika 2016).

Pengujian antibakteri ekstrak daun ketepeng cina dilakukan secara in vitro menggunakan difusi disk (Kirby Bauer) dengan pengulangan sebanyak 3 kali. Pengujian ini diawali dengan pembuatan suspensi bakteri Staphylococcus aureus, Pseudomonas aerogenosa, dan Klebsiella pneumonia dengan cara penambahan larutan $\mathrm{NaCl} 0,9 \%$ hingga didapatkan kekeruhan yang sesuai standar Mc Farland 0,5.

Suspensi bakteri uji diinokulasikan ke media Mueller Hinton Agar. Disk yang telah berisi ekstrak, etanol (kontrol negatif) dan chloramphenicol (kontrol positif) diletakkan pada media bakteri. Kemudian dilakukan 
inkubasi selama 24 jam pada suhu $37^{\circ} \mathrm{C}$ dan diukur diameter zona hambatnya pada area sekitar disk antibakteri.

\section{Hasil}

Uji Aktivitas Antibakteri

Pengujian aktivitas antibakteri ekstrak daun ketepeng cina (Cassia alata L.) terhadap bakteri Staphylococcus aureus, Pseudomonas aerogenosa, dan Klebsiella pneumonia dilakukan dengan tiga kali ulangan. Rata-rata diameter zona hambat pertumbuhan bakteri dapat dilihat pada Tabel 1.

Tabel 1. Diameter Zona Hambat Pertumbuhan Bakteri

\begin{tabular}{|c|c|c|c|}
\hline \multirow{2}{*}{ Konsentrasi } & \multicolumn{3}{|c|}{$\begin{array}{l}\text { Rata-rata Diameter Zona Hambat } \\
\text { Pertumbuhan Bakteri }(\mathrm{mm})\end{array}$} \\
\hline & $\begin{array}{c}S . \\
\text { aureus }\end{array}$ & $\begin{array}{c}\text { Pseudomonas } \\
\text { aerugenosa }\end{array}$ & $\begin{array}{c}\text { Klebsiella } \\
\text { pneumonia }\end{array}$ \\
\hline $10 \%$ & 5 & 6.8 & 4.8 \\
\hline $30 \%$ & 7.2 & 8.9 & 7.1 \\
\hline $50 \%$ & 7.6 & 13.2 & 7.4 \\
\hline $70 \%$ & 12.5 & 13.3 & 9.8 \\
\hline $90 \%$ & 12.2 & 16.2 & 13.7 \\
\hline $\begin{array}{l}\text { Kontrol } \\
\text { Positif }\end{array}$ & 20.3 & 7.5 & 12.6 \\
\hline $\begin{array}{l}\text { Kontrol } \\
\text { negatif }\end{array}$ & 0 & 0 & 0 \\
\hline
\end{tabular}

Tabel 1. menunjukkan bahwa masingmasing konsentrasi ekstrak ketepeng cina memberikan diameter zona hambat yang berbeda begitu pula dengan kontrol positif dan kontrol negatif. Pada kontrol positif terbentuk zona bening yang menunjukkan adanya aktivitas antibakteri dan pada kontrol negatif tidak terbentuk zona bening yang menunjukkan tidak adanya aktivitas antibakteri.

Uji Fitokimia Ekstrak Daun Ketepeng Cina

Hasil pengujian fitokimia ekstrak daun ketepeng cina (Cassia alata L.) dapat dilihat pada Gambar 1. dan Tabel 2.

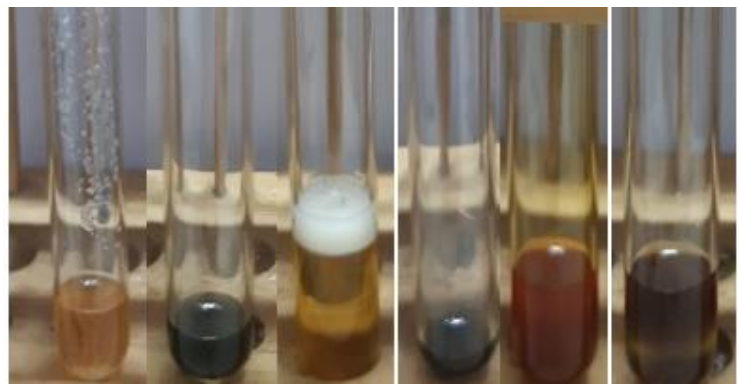

Gambar 1. Hasil Pengujian Fitokimia
Tabel 2. Hasil Pengujian Fitokimia

\begin{tabular}{clcl}
\hline No & Uji Fitokimia & Hasil & Keterangan \\
\hline 1 & Flavonoid & + & Berwarna jingga \\
2 & Tanin & + & Hijau tua \\
3 & Saponin & + & Berbusa \\
4 & Fenolik & + & Hijau tua \\
5 & Alkaloid & + & Endapan jingga \\
6 & Terpenoid & - & Tidak terbentuk \\
7 & Steroid & - & Coklat muda \\
\hline
\end{tabular}

Catatan : (+) terdapat kandungan fitokimia

(-) tidak terdapat kandungan fitokimia

Tabel 2. Menunjukkan bahwa ekstrak etanol daun ketepeng cina yang digunakan dalam penelitian ini mengandung flavonoid, tannin, saponin, fenol dan alkaloid.

\section{Pembahasan}

Metode ekstraksi yang digunakan dalam penelitian ini adalah maserasi. Maserasi dilakukan dengan cara perendaman serbuk daun ketepeng cina dalam pelarut dan waktu tertentu, dalam hal ini pelarut yang digunakan adalah etanol. Hasil ekstraksi kemudian dipekatkan dan digunakan untuk uji aktivias antibakteri terhadap Staphylococcus aureus, Pseudomonas aeruginosa, dan Klebsiella pneumonia. Aktivitas antibakteri ditandai dengan terbentuknya zona bening (hambat) pada media bakteri uji.

Zona bening yang terbentuk disebabkan karena kandungan senyawa fitokimia dalam ekstrak daun ketepeng cina seperti flavonoid, tannin, saponin, fenol dan alkaloid (Tabel 2.). Hasil penelitian ini sedikit berbeda dengan penelitian sebelumnya yang mengidentifikasi adanya senyawa alkaloid, triterpenoid, steroid, dan kuinon dalam ekstrak daun ketepeng cina (Mawaddah, E, and Saleh 2020).

Mekanisme kerja antibakteri senyawa flavonoid yaitu melalui interaksi dengan beberapa enzim vital dan penghambatan sintesis asam nukleat serta fungsi membran sitoplasma (Adamczak, Ożarowski, and Karpiński 2019). Selain itu, flavonoid juga dapat menghambat metabolisme aerob yang menyebabkan sel menjadi lisis karena tidak memiliki energi (Pragita et al. 2020).

Tanin memiliki aktivitas antibakteri melalui penghambatan kerja enzim reverse transcriptase dan DNA topoisomerase. Tanin juga mempresipitasi protein pada lapisan dalam 
sel sehingga transport protein di dalam sel menjadi terganggu. Hal ini menyebabkan sel bakteri tidak terbentuk (Rijayanti, Luliana, and Trianto 2014).

Saponin merupakan senyawa yang mirip dengan deterjen, yang dapat mengeluarkan bus ajika dikocok. Karena mirip dengan deterjen, maka saponin dapat menurunkan tegangan permukaan dinding sel bakteri dan merusak permeabilitas membran sel bakteri. Akibatnya kelangsungan hidup bakteri menjadi terganggu karena adanya kebocoran pada sitoplasma (Sani et al. 2014).

Senyawa fenol dalam ekstrak daun ketepeng cina dapat menyebabkan lisisnya dinding sel bakteri dan mengakibatkan kebocoran pada dinding sel. Zat-zat penting yang dibutuhkan oleh bakteri akan keluar dari sel dan digantikan oleh fenol. Di dalam sel fenol akan merusak sistem kerja sel, merusak membran sitoplasma, mengganggu pertumbuhan bahkan menyebabkan kematian sel, mendenaturasikan protein dan asam nukleat, serta menghambat sintesis asam nukleat dan protein (Ngazizah, Ekowati, and Septiana 2017).

Alkaloid memiliki daya antibakteri dengan cara menghambat kerja enzim topoisomerase dan membentuk khelat dengan DNA. Senyawa alkaloid juga menghambat sintesis dinding sel bakteri, sehingga sel bakteri menjadi lisis dan kehilangan bentuk (Ningsih, Zusfahair, and Kartika 2016).

Diameter zona bening yang terbentuk dari masing-masing bakteri dan konsentrasi ekstrak berbeda-beda, yakni antara 4,8 $\mathrm{mm}-$ $16,2 \mathrm{~mm}$. Perbedaan diameter zona hambat yang terbentuk disebabkan karena perbedaan konsentrasi ekstrak dan jenis bakteri uji yang digunakan (Egra et al. 2019). Diameter zona hambat yang terbentuk mengalami kenaikan seiring dengan bertambahnya konsentrasi. Hal ini dikarenakan dalam ekstrak yang berkonsentrasi tinggi, kandungan senyawa aktif antibakterinya juga tinggi (Yacob and Endriani 2012). Penghambatan terbesar ditunjukkan pada konsentrasi ekstrak 90\% dengan diameter 12.2 $\mathrm{mm}$ untuk Staphylococcus aureus, $16.2 \mathrm{~mm}$ untuk Pseudomonas aerogenosa, dan $13.7 \mathrm{~mm}$ untuk Klebsiella pneumonia (Tabel 1.). Hal ini membuktikan bahwa daya antibakteri suatu ekstrak dipengaruhi oleh konsentrasi.

Hasil analisis statistik menggunakan ANOVA satu arah didapatkan perbedaan diameter zona hambat yang signifikan antar jenis bakteri dan konsentrasi $(\mathrm{p}=0,000)$. Hasil yang didapatkan dari analisis Post-Hoc dapat disimpulkan bahwa aktivitas antibakteri tertinggi terhadap bakteri Staphylococcus aureus yakni pada konsentrasi $70 \%$ dan terhadap bakteri Pseudomonas aeruginosa, serta Klebsiella pneumonia aktivitas antibakteri tertingginya pada konsentrasi $90 \%$.

Perbedaan bakteri uji yang digunakan juga mempengaruhi diameter zona hambat yang terbentuk. Staphylococcus aureus merupakan bakteri gram positif yang struktur dinding selnya berlapis tunggal, sedangkan Pseudomonas aeruginosa dan Klebsiella pneumonia merupakan bakteri gram negatif yang struktur dinding selnya berlapis tiga (Boleng 2015). Dinding sel bakteri gram positif tersusun atas protein dan karbohidrat, sedangkan dinding sel bakteri gram negatif tersusun atas protein, karbohidrat, dan lipid (Ananthanarayan and Paniker 2017). Ekstrak etanol ketepeng cina mempunyai daya antibakteri terhadap S. aureus (gram positif) tetapi tidak mempunyai daya antibakteri terhadap E. coli (gram negatif) (Yacob and Endriani 2012).

Karena ekstrak yang dihasilkan dalam penelitian ini agak encer, maka hasil yang berbeda diperoleh dalam penelitian ini. Lapisan terluar dari dinding sel bakteri gram negatif yaitu lipid akan terlarut oleh etanol yang masih tersisa dalam ekstrak (Yusminar, Wardiyah, and Nida 2017). Hal ini mengakibatkan diameter zona hambat yang dihasilkan oleh Pseudomonas aeruginosa dan Klebsiella pneumonia relatif lebih luas dibanding Staphylococcus aureus. Penyebab lain yang terjadi adalah senyawa flavonoid lebih kuat menghambat pertumbuhan bakteri gram negatif daripada gram positif (Adamczak, Ożarowski, and Karpiński 2019).

Dilihat dari dimeter zona hambat yang terbentuk, kekuatan antibakteri dari ekstrak daun ketepeng cina (Cassia alata L.) termasuk dalam kategori sedang. Kekuatan antibakteri dikategorikan menjadi empat yaitu : lemah (zona hambat $<1 \mathrm{~cm}$ ), sedang (zona hambat $1-$ $1,5 \mathrm{~cm}$ ), kuat (zona hambat $1,6-2 \mathrm{~cm}$ ), dan sangat kuat (zona hambat $>2 \mathrm{~cm}$ ) (Rumayar et al. 2020). Pada konsentrasi ekstrak yang paling efektif untuk bakteri Pseudomonas aeruginosa dan Klebsiella pneumonia diameter zona hambat yang terbentuk lebih besar dari kontrol positif yang digunakan, sehingga dapat dikatakan pada konsentrasi tersebut kekuatan antibakteri ekstrak lebih tinggi dari chloramphenicol. Akan tetapi, pada konsentrasi ekstrak yang paling efektif untuk bakteri Staphylococcus aureus hal ini tidak berlaku. 
Kekuatan antibakteri ekstrak untuk bakteri Staphylococcus aureus masih lebih rendah dari chloramphenicol.

Chloramphenicol merupakan antibiotik yang memiliki spektrum luas dan mampu menghambat bakteri gram positif dan gram negatif (Egra et al. 2019). Hasil penelitian ini menunjukkan diameter zona hambat chloramphenicol terhadap bakteri Pseudomonas aerogenosa paling kecil dibanding yang lain. Hal ini dikarenakan resistensi Pseudomonas aeruginosa terhadap berbagai jenis antibiotika, salah satunya chloramphenicol (Olivia 2017).

Simpulan penelitian ini adalah ekstrak daun ketepeng cina (Cassia alata L.) memiliki aktivitas antibakteri terhadap bakteri Staphylococcus aureus, Pseudomonas aeruginosa dan Klebsiella pneumonia. konsentrasi $70 \%$ memiliki aktivitas antibakteri tertinggi terhadap bakteri Staphylococcus aureus, konsentrasi $90 \%$ memiliki aktivitas antibakteri tertinggi terhadap bakteri Pseudomonas aeruginosa, dan Klebsiella pneumonia.

Berdasarkan hasil penelitian ini, perlu dilakukan penelitian lanjut mengenai daya antibakteri daun ketepeng cina (Cassia alata L.) terhadap bakteri lain dan juga menggunakan konsentrasi ekstrak dan pelarut yang lain.

\section{Ucapan Terima Kasih}

Terima kasih disampaikan kepada DRPM Dikti yang telah mendanai pelaksanaan penelitian ini melalui Hibah Penelitian Dosen Pemula tahun anggaran 2020.

\section{Daftar Pustaka}

Adamczak, Artur, Marcin Ożarowski, and Tomasz M. Karpiński. 2019. "Antibacterial Activity of Some Flavonoids and Organic Acids Widely Distributed in Plants." Journal of Clinical Medicine 9(1): 109.

Ananthanarayan, and Paniker. 2017. Textbook of Microbiology Tenth Edition. ed. Reba Kanungo. India: Universities Press.

Anggraini, Dewi, Utari Gusti Yulindra, and Maya Savira. 2018. "Prevalensi Dan Pola Sensitivitas Antimikroba Multidrug Resistant Pseudomonas Aeruginosa Di RSUD Arifin Achmad." Majalah Kedokteran Bandung 50(1): 6-12.
Boleng, Didimus Tanah. 2015. Bakteriologi Konsep-Konsep Dasar. Malang: UMM Press.

Egra, S., Mardiana, A. Kurnia, and H. Kuspradini Kartina, A. Murtilaksono. 2019. "Uji Potensi Ekstrak Daun Tanaman Ketepeng (Cassia Alata L) Dalam Menghambat Pertumbuhan Bakteri Ralstonia Solanacearum Dan Streptococcus Sobrinus." Ulin - J Hut Trop 3(1): 25-31.

Kementerian Kesehatan Republik Indonesia. 2012. Profil Kesehatan Indonesia Tahun 2011. Jakarta: Kementerian Kesehatan Republik Indonesia.

Mawaddah, Izkia, Erwin E, and Chairul Saleh. 2020. "Skrining Fitokimia, Uji Toksisitas Dan Uji Peredaman Radikal DPPH Ekstrak Daun Gelinggang (Cassia Alata L).” KOVALEN: Jurnal Riset Kimia 6(1): 61-66.

Murni, Gunawan, and Brian Janitra. 2014. "Efektivitas Ekstrak Etanol Daun Ketepeng (Cassia Alata L.) Dan Ketepeng Kecil (Cassia Tora L.)Terhadap Plasmodium Falciparum Secara In Vitro.” Balaba 10(02): 83-88.

Ngazizah, Febri Nur, Nuraeni Ekowati, and Aisyah Tri Septiana. 2017. "Potensi Daun Trembilungan (Begonia Hirtella Link) Sebagai Antibakteri Dan Antifungi." Biosfera 33(3): 126.

Ningsih, Dian Riana, Zusfahair, and Dwi Kartika. 2016. "Identifikasi Senyawa Metabolit Sekunder Serta Uji Aktivitas Ekstrak Daun Sirsak Sebagai Antibakteri." Molekul 11(1): 101-11.

Novard, M. Fadila Arie, Netti Suharti, and Roslaili Rasyid. 2019. "Gambaran Bakteri Penyebab Infeksi Pada Anak Berdasarkan Jenis Spesimen Dan Pola Resistensinya Di Laboratorium RSUP Dr. M. Djamil Padang Tahun 20142016." Jurnal Kesehatan Andalas 8(2S): 26.

Nurlansi, and Jahidin. 2018. "Uji Aktivitas Antibakteri Ekstrak Metanol Dan Fraksi Etilasetat Daun Ketepeng Cina (Casia Alata L)." Indonesia Natural Research 
Pharmaceutical Journal 2(2): 13-18.

Olivia, Corry Khathreen. 2017. "Infeksi Pseudomonas Aeruginosa Dan Klebsiella Pneumoniae Ssp Pneumoniae Pada Ulkus Kruris Et Femoralis Pada Pasien Diabetes Melitus Type II." Fakultas Kedokteran Unud/Rs Sanglah Denpasar 8: 1-20.

Pragita, Anisa Sri, Dheanna Putri Shafa, Devi Nursifah, and Alfi Rumidatul. 2020. "Uji Aktivitas Antimikroba Ekstrak Kulit Dan Kayu Sakit Ranting Sengon Terhadap Bakteri Dan Jamur." Jurnal Analis Kesehatan 9(2): 41-48.

Putri, Ayu Andrian, Roslaili Rasyid, and Rahmatini Rahmatini. 2014. "Perbedaan Sensitivitas Kuman Pseudomonas Aeruginosa Penyebab Infeksi Nosokomial Terhadap Beberapa Antibiotika Generik Dan Paten.” Jurnal Kesehatan Andalas 3(3): 327-31.

Rijayanti, Rika Pratiwi, Sri Luliana, and Heru Fajar Trianto. 2014. "In Vitro Antibacterial Activity Test Of Ethanol Extracts Bacang Mango (Mangifera Foetida L.) Leaves Against Staphylococcus Aureus." Naskah Publikasi Universitas Tanjungpura 1(1): 10-12.

Rumayar, Ricky C, Paulina V Y Yamlean, Jainer Pasca Siampa, and Volume Nomor Agustus. 2020. "Formulasi Dan Uji Aktivitas Antijamur Sediaan Krim Ekstrak Metanol Ketepeng Cina ( Cassia Alata L .) Terhadap Jamur Candida Albicans." Pharmacon 9: 365-71.

Sani, Robby Nasrul, Fithri Choirun Nisa, Ria Dewi Andriani, and Jaya Mahar Maligan. 2014. "Analisis Rendemen Dan Skrining Fitokimia Ekstrak Etanol Mikroalga Laut Tetraselmis Chuii." Jurnal Pangan dan Agroindustri 2(2): 121-26. https://jpa.ub.ac.id/index.php/jpa/article/v iew/44.

Yacob, Taswin, and Rita Endriani. 2012. "Daya Antibakteri Ekstrak Etanol Ketepeng Cina (Senna Alata) Terhadap Staphylococcus Aureus Dan Escherichia Coli Secara In Vitro." Jurnal Natur Indonesia 13(1): 63.
Yusminar, Wardiyah, and Khairun Nida. 2017. Mikrobiologi Dan Parasitologi. Jakarta: Kementerian Kesehatan Republik Indonesia. 